Dlouhý A., Trojanová Z., Lukáč P.: Thermally (non-) activated deformation of $Z r-S n$ poly-

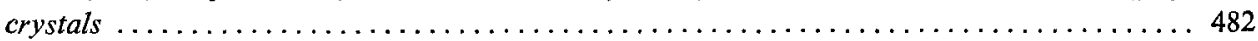

Balík J., Janeček M., Mencl J.: Dynamic strain ageing in CuNiSn alloys............ 485

Saxlová M.: Activation energy of high temperature steady state deformation in hcp metals... . 488 Lukáč P., Trojanová Z., Chmelík F., Hamerský M., Moskalenko V. A.: Thermally activated

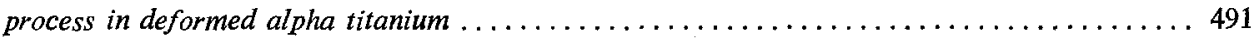

Haasen P.: Stage IV work hardening of metals and semiconductors .............. 494

Milička K.: Steady state creep in zinc as a result of thermally activated glide of dislocations. . 498

Orlová A.: On the mobile dislocation density in creep ...................... 502

Burton B.: A dislocation network model of creep transients after a stress dip.......... 505

Neuhäuser H., Arkan O. B., Flor H.: Dynamics of slip band formation in fcc alloys....... 511

Feltham P.: Mechanical effects in the $n \rightarrow$ s transition of work-hardened metal and alloy super-

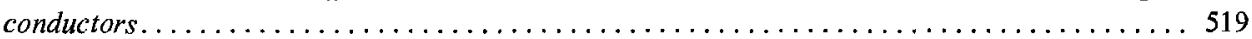

Dobeš F.: Internal stresses in the model of hard and soft regions................. 524

Sprušil B., Fritsch H.-U., Mordike B. L.: The influence of work hardening and softening on

the space-time character of single slip deformation - a computer simulation.......... 527

Wyslych P., Mazanec K., Hyspecká L.: Deformation characteristics of as quenched martensite 530

\title{
Erratum \\ SOFTENING DURING AND AFTER THE HOT DEFORMATION OF THE AISI 321 STEEL WITH RESPECT TO PRACTICAL APPLICATIONS
}

\author{
Havela L., Kratochvíl P., Lukáč P., Smola B., Svobodová A. \\ Proc. 4th Internat. Symp. Plasticity of Met. \& Alloys, Part I \\ Czech. J. Phys. B 38 (1988), No 4, 384
}

P. 384: The correct value of the activation energy $Q$ is $Q=456 \mathrm{~kJ} / \mathrm{mol}(4.7 \mathrm{eV})$. 